International Journal of Engineering \& Technology, $7[2.29][2018] 655-659$
International Journal of Engineering \& Technology
SPC
Website: www.sciencepubco.com/index.php/IJET
Research paper

\title{
Communication Strategies Among Tertiary Students in Mlearning
}

\author{
Shahirah Sulaiman ${ }^{1 *}$, Supyan Hussin², Zaini Amir ${ }^{3}$ \\ ${ }^{1}$ Tamhidi Centre, Universiti Sains Islam Malaysia \\ ${ }^{2,3}$ Faculty of Social Sciences \& Humanities, Universiti Kebangsaan Malaysia \\ *Corresponding Author E-Mail: Sha6884@Hotmail.Com
}

\begin{abstract}
The relentless wave of using mobile device in Malaysia, as a tool for teaching and learning in educational setting is incontestable. Multitudinous tertiary institutions have adapted this technology in their academic system; due to its approach which aids synchronous and asynchronous learning towards achieving educational outcomes. In spite of the rapid expansion medium employed in mobile learning [mLearning], students' communicative competence in academic context is a major concern, especially when they are communicating in their native languages or being a bilingual user of the English language. Hence, this paper addresses the communication strategies in mLearning among tertiary students based on a quantitative research design conducted at Universiti Sains Islam Malaysia. The data were gathered from 125 students using a questionnaire which measured the learners' frequency of the communication strategies used. Findings showed that the communication in mobile indicated that students employed varying degrees of communication strategies in mLearning. The results reflected an overview of students' interaction in mLearning setting as it could be used to benefit academicians in assisting students with their communicative competence not only in- yet also out- of the mLearning context. Thus, several implications were further discussed in this study.
\end{abstract}

Keywords: Communication strategies; Tertiary Students; mLearning; communicative competence; interaction

\section{Introduction}

The use of mobile in Malaysia's tertiary institutions for educational activities is irrefutably being practiced among academicians and students. It has been exploited as an effective tool in learning and teaching session, as [1] stated that, "the value of deploying mobile technologies in the service of learning and teaching seems to be both self-evident and unavoidable." The use of mobile in learning or is known as mLearning, in which the letter " $\mathrm{m}$ " refers to "mobile"; does not confined merely in physical classroom activities but help students to pace their studies in open or distance learning. The mLearning features which include flexibility and accessibility at anytime and anywhere are suitable for the synchronous as well as asynchronous educational activities. This is paralleled with [2] study that there are many learning opportunities for higher education students to experience the development of mobile technologies with such multifaceted learning milieu. In addition, mLearning activities are helpful in motivating and encouraging interaction among students [3]. It is a personalized interactive technology to acquire knowledge via exchange communication through various contexts among academicians and students. In particular, by using mobile gadgets it facilitates teaching and learning activities in seeking information, comparing data, reading reports or articles and as a mean of communication.

For the purpose of discussion, mLearning is defined as a mode of learning process using mobile gadgets such as smart phones or tabs to meet the given learning outcomes. Most students own a smart phone or tab in higher learning institutions. Essentially, as mLearning is postulated as "personal, spontaneous, disruptive, opportunistic, informal, pervasive, situated, private, context-aware, bite-sized, and portable" [4], the exchange communication occurred in academic context is a major concern. It is significant in an academic communication to be in an interactive process between the educator and students for educational outcomes [5]. In an mLearning environment, students may be informal, absent or disengage neither conscious nor unconsciously during the communication in comparison to physically face-to-face communication. In [6] study revealed that it was hard for the respondents to foster their interaction in mLearning with the lecturer as it was incomprehensible. Thus, this is imperative, as it is vital in a teaching-learning and communication process regardless in or out of the classroom setting; in identifying the lesson difficulties faced by students, acknowledging students' understanding of the lesson learnt, avoiding the misunderstand between the lecturer-students and students-students conversations as well as promoting communication strategies in an appropriate manner for such educational activities.

\section{Literature Review}

\subsection{Communication Strategies}

There are many studies conducted on face-to-face or oral communication strategies but minimal on mLearning communication strategies. In this study as it is a mLearning setting, as regardless of its means of communication; it does involve a communication process between a speaker and addressee cognitively, socially and ethically. This is crucial in academic perspectives as to preserve the lecturer-students and student-students relationship, to deliver and receive the lesson's content respectively, in addition to culti- 
vate a communicative competence community through mLearning activities. In this context, tertiary students and lecturers would communicate to exchange and share messages or information in their lessons using mobile. At times, communication breakdowns would occur and lead to misunderstanding. Most likely, this could happen if the students' language proficiency or background is different from one another.

This would be difficult and might instigate miscommunication and misinformation retrieved in the mLearning activities. As a result, they will definitely use communication strategies as "to overcome the inadequacies of their inter-language resources" [7]. Communication strategies are also known as an individual's communication attempt in using instant available linguistics knowledge to fill the gap between their communication content [8]. The strategies are crucial to be used as when a mutual attempt of two interlocutors; a speaker and an addressee, agree on a meaning in a situation of interaction that takes place in which requisite meaning structures does not happen [9]. Therefore, by implying such communication strategies, it could maintain the conversational flow, especially in educational context.

Since 1970s, as studies of communication strategies have been done, the number of taxonomies of communication strategies were constructed by [10], [11], [12], [13] as well as [14] in order to recognize the comprehensible conversation process of students' input and output in a communication. Especially, the execution of communication strategy skills or is known as strategic competence; is one of the subset component in communicative competence of language use that focuses in delivering and receiving meaningful messages [11]. Hence, it is necessary to refer to it as a guideline of observing the limitations or achievement of the tertiary students in mLearning communication.

When students deal with problems in communication via mLearning, they might either avoid the problem or find some sort of alternative solution. Hence, the two main communication strategies that will be discussed and implied in this study are; avoidance strategy and compensatory strategy. This is because students will usually solve communication problems [15] by changing the communicative goals [avoidance strategies] or by developing an alternative plan [compensatory strategies]. It can also be characterized that avoidance strategies as "risk-avoiding" and compensatory strategies as "risk-taking" [16].

\subsection{Avoidance Strategy}

"Avoidance strategies" can be categorized into several subtypes, such as "phonological avoidance, syntactic or lexical avoidance and topic avoidance" [17] . These strategies may not be a helpful way for students to learn or acquire a new language; even so, it is an effective way in keeping up the communication flow. For example, when students are asked a specific question, the student who does not know the answer will not participate or respond as he or she will keep silent, and this will lead towards "topic avoidance". Consequently, the student will employ such strategy as topic avoidance as the most frequent medium in their communication strategies. Perhaps this might be due to students hardly convey their ideas or answers in a flexible way; as they might seldom practice English language and they do not have acquired basic knowledge of the language. Generally, this happens when students deal with anxiety and apprehension due to their insufficient vocabulary [18], lack of confidence [19], and fear of negative evaluation to make mistakes when speaking English in front of their classmates [20].

\subsection{Compensatory Strategy}

Meanwhile, by using "compensatory strategies", students attempt to increase their language knowledge in order to understand and respond towards the interaction. [12] argue that only compensatory strategies have the potential learning effect. It is stimulated when students, compensates the incomplete meaning of a communication delivered as to maintain the communicative goal. By using compensatory, or also known as "achievement strategies", it intends to reduce communication hiccups in the planning phase of a communication process due to insufficient linguistic resources [12]. The compensatory strategies are subcategorized as: a different code ["code switching" and "interlingual transfer"], a different code and the interlanguage code simultaneously ["inter/intralingual transfer"], the interlanguage code exclusively ["generalization" and "paraphrase".], discourse phenomena [i.e. "appeals"], and non-linguistic devices ["mime"].

Moreover, [13] summarizes eleven types of compensatory strategies in a very comprehensive way including circumlocution, word coinage, foreignizing, prefabricated patterns, appealing for help and stalling for time-gaining strategies. Some of them happened more frequently in a communication setting, while others are not: for example, "foreignizing", which refers to "use the first language [L1] word by adjusting it to the second language [L2] phonology and/or morphology". In such circumstances, it could happen that students might find it hard to substitute the pronunciation of an English word; then, they simply add an English suffix to their native language to ease the mutual understanding in the communication individually and collectively. On that note, there are intra-actional and inter-actional strategies under the compensatory strategies components. Table 1 presents the integrated taxonomy of the communication strategies constructed based on earlier ideas on avoidance strategies and compensatory strategies along with the categories of intra-actional and inter-actional strategies provided by [14], [21], as well as [12].

Table 1: Taxonomies of Communication Strategies

\begin{tabular}{|c|c|c|}
\hline \multicolumn{2}{|c|}{ Communication Strategy } & \multirow{2}{*}{ Definition } \\
\hline \multicolumn{2}{|r|}{ 1. Avoidance Strategies } & \\
\hline $1.1 \mathrm{~T}$ & Topic avoidance & $\begin{array}{l}\text { Reducing the message by avoiding cer- } \\
\text { tain language structures or topics consid- } \\
\text { ered problematic language or by leaving } \\
\text { out some intended elements for a lack of } \\
\text { linguistic resources. }\end{array}$ \\
\hline $1.2 \mathrm{~N}$ & Message abandonment & $\begin{array}{l}\text { Expressing a target concept and suddenly } \\
\text { stopping in mid-sentence, chooses an- } \\
\text { other topic and continues the conversa- } \\
\text { tion. }\end{array}$ \\
\hline & $\begin{array}{l}\text { 2. Compensatory } \\
\text { strategies }\end{array}$ & $\begin{array}{l}\text { Achievement or compensatory strategies } \\
\text { help speakers to sustain their communi- } \\
\text { cation via alternative plans }\end{array}$ \\
\hline & Intra-Actional Strategies & $\begin{array}{l}\text { By using intra-actional strategies learn- } \\
\text { ers try to solve problems by themselves, } \\
\text { without seeking help from other people }\end{array}$ \\
\hline 2.1 .1 & Word coinage & $\begin{array}{l}\text { Coining words is a form of paraphrasing } \\
\text { to make up a word to substitute for un- } \\
\text { known word }\end{array}$ \\
\hline 2.1 .2 & Code switching & $\begin{array}{l}\text { Including L1/L3 words with L1/L3 pro- } \\
\text { nunciation in L2 speech. This may in- } \\
\text { volve stretches of speech ranging from } \\
\text { single words to whole chunks and even } \\
\text { complete turns }\end{array}$ \\
\hline 2.1 .3 & Foreignizing & $\begin{array}{l}\text { Using a L1 word by adjusting it to L2 } \\
\text { phonology [i.e., with a L2 pronunciation] } \\
\text { and/or morphology }\end{array}$ \\
\hline $\begin{array}{l}2.1 .4 \\
\text { means }\end{array}$ & Use of non-linguistic & $\begin{array}{l}\text { Describing whole concepts nonverbally, } \\
\text { or accompanying a verbal strategy with a } \\
\text { visual illustration }\end{array}$ \\
\hline 2.1 .5 & Self-Repair & $\begin{array}{l}\text { making self-initiated corrections in one's } \\
\text { own speech }\end{array}$ \\
\hline 2.1 .6 & Mumbling & $\begin{array}{l}\text { Swallowing or muttering inaudibly a } \\
\text { word [or part of a word] whose correct } \\
\text { form the speaker is uncertain about }\end{array}$ \\
\hline 2.1 .7 & Use of all- purpose & $\begin{array}{l}\text { Extending a general, empty lexical item } \\
\text { to contexts where specific words are } \\
\text { needed [e.g., the overuse of thing, stuff, } \\
\text { someone, something make, do, thingie, } \\
\text { what-do-you-call-it] }\end{array}$ \\
\hline 2.1 .8 & Approximation & Using a single target language vocabu- \\
\hline
\end{tabular}




\begin{tabular}{|c|c|c|}
\hline & & $\begin{array}{l}\text { lary item that he/she may know is not } \\
\text { correct but shares enough semantic fea- } \\
\text { tures with the desired item to satisfy the } \\
\text { speaker }\end{array}$ \\
\hline 2.1 .9 & Circumlocution & $\begin{array}{l}\text { Explaining the characteristics of the } \\
\text { object or action he is describing instead } \\
\text { of using the target language item }\end{array}$ \\
\hline 2.1.10 & Litera & $\begin{array}{l}\text { Translating literally a lexical item, an } \\
\text { idiom, a compound word or structure } \\
\text { from L1/L3 to L2 }\end{array}$ \\
\hline 2.1 .11 & Use of fillers & $\begin{array}{l}\text { Using various devices to facilitate the } \\
\text { oral communication and to compensate } \\
\text { when communication is unsuccessful. }\end{array}$ \\
\hline 2.1.12 & Self-Rep & $\begin{array}{l}\text { Repeating some speech segments to buy } \\
\text { some more time in order to retrieve the } \\
\text { required speech segment, and maintain } \\
\text { conversation. }\end{array}$ \\
\hline 2.1 .13 & Othe & $\begin{array}{l}\text { To repeat something the interlocutor said } \\
\text { to gain time. }\end{array}$ \\
\hline 2.1 .14 & Omis & $\begin{array}{l}\text { leaving a gap when not knowing a word } \\
\text { and continue as if it had been said }\end{array}$ \\
\hline $2.2 \mathrm{In}$ & ractional Strategies & $\begin{array}{l}\text { In the interactional view the main focus } \\
\text { is on the mutual negotiation of meaning } \\
\text { between the speakers. }\end{array}$ \\
\hline 2.2 .1 & Asking for repetition & $\begin{array}{l}\text { It happens when learners do not hear or } \\
\text { understanding something. }\end{array}$ \\
\hline 2.2 .2 & Appeal for help & Asking for help directly or indirectly \\
\hline 2.2 .3 & Clarification request & $\begin{array}{l}\text { Requesting for more explanation to solve } \\
\text { a comprehension difficulty }\end{array}$ \\
\hline $\begin{array}{l}2.2 .4 \\
\text { tion }\end{array}$ & Asking for confirma- & $\begin{array}{l}\text { Requesting confirmation that one heard } \\
\text { or understood something correctly }\end{array}$ \\
\hline $\begin{array}{l}2.2 .5 \\
\text { check }\end{array}$ & Comprehension & $\begin{array}{l}\text { Asking questions to check that interlocu- } \\
\text { tor can follow you }\end{array}$ \\
\hline $\begin{array}{l}2.2 .6 \\
\text { underst }\end{array}$ & $\begin{array}{l}\text { Expressing non } \\
\text { ding }\end{array}$ & $\begin{array}{l}\text { Expressing that one did not understand } \\
\text { something properly either verbally or } \\
\text { nonverbally }\end{array}$ \\
\hline
\end{tabular}

As mentioned earlier, this study seek the mLearning communication strategies used among the tertiary students; some of the strategies remained, replaced and added as to cater for the mLearning context. On that note, some of the communication strategies' taxonomies that were discussed and implied in previous studies as $[13,16,22]$ and $[23,24]$,were also chosen and used to complement this study's communication strategies' taxonomy accordingly.

\section{Methodology}

\subsection{Respondents and Setting}

This exploratory study took place at Universiti Sains Islam Malaysia [USIM] among the first year undergraduates who were in their second semester. This purposive sampling has at least a year of mLearning experience and passed their English's Malaysia Secondary School Examination Certificate or is known as Sijil Peperiksaan Malaysia [SPM] along with the minimum of Band 2 to Band 6 in their Malaysia English University Test [MUET]. These 125 students experienced mLearning in their foundation year or pre-university course in Tamhidi Centre at Universiti Sains Islam Malaysia [USIM] previously.

\subsection{Procedure}

The teaching and learning process in this course, English for Communication [UBE 1092], is focused on the application of various skills through activities; both inside and outside of the classroom, as in synchronous and asynchronous settings. The syllabus is designed to achieve a balance between each language skill: reading, writing, speaking and listening, with a strong emphasis on the usage of grammar and vocabulary in context.
As this study aims to investigate the mLearning communication strategies used, the students' syllabus were designed to have 12 weeks' task-based activities involving the use of mobile phone application, Telegram. The assessments are carried out continuously, and geared towards developing students to achieve a satisfactory level in the language. The class was held for 2 hours of face-to-face in a week, in which the students communicated and submitted their tasks in classroom and mLearning context in accordance with the week's lessons activity.

\subsection{Instrument}

A set of Likert-scale questionnaire, containing 24 items based on Communications Strategies Taxonomies, was distributed to students after they completed their 12 weeks lessons. The scales were ranged as follows: Never [1], Sometimes [2], Often [3], and Always [4]. The Communications Strategies Taxonomies were referred to the incorporated taxonomy of the communication strategies structured by [14], [21], as well as [12]; on avoidance strategies and compensatory strategies along with the categories of intra-actional and inter-actional strategies.

On that note, some of the communication strategies' taxonomies that were discussed and implied in previous studies as [13, 16, $22]$ and $[23,24]$ were chosen and used to complement this study of communication strategies' taxonomy respectively. As a result, some of the strategies were remained, replaced and added to as to cater for students' mLearning communication strategies context.

\subsection{Data Analysis}

In this study, descriptive analysis was carried out using SPSS v.22, in order to capture the frequency distribution of the data in the forms of means and standard deviation. The number of communication strategy were calculated in terms of means and percentages, and later presented in tabular forms. The questionnaire items used in this study were validated for its reliability using Cronbach's Alpha values. The Alpha value for these 24 items was .715, which illustrates highly acceptable internal consistency. The mean for these 24 items was 66.59 and its standard deviation was 6.88403 .

\section{Results and Findings}

Based on the results of 125 students' answers in the questionnaire, data are presented in; Table 2 indicating Avoidance Strategies, while, Table 3 depicts Compensatory Strategies [IntraActional], and Table 4 displays Compensatory Strategies [InterActional] used among tertiary students in mLearning context.

In Table 2, it shows that as the mean score for Avoidance Strategies was 2.2000, most of the students answered "Sometimes" [48\%] in spite of "Always" [4.8\%] in using Topic Avoidance for their communication strategies in mLearning context. Meanwhile, students answered "Often" [45.6\%] to surprisingly "Never" [8\%] of Message Abandonment as their Avoidance Strategies in such set. This depicts that such students who are lack of appropriate communication strategies have no choice other than to end the communication as supported by [13] as well as [12]; that even though these might be mutual understanding or occurred in communication context, however, these are known as negative strategies.

\begin{tabular}{|c|c|c|c|c|c|c|}
\hline $\begin{array}{l}\text { Freq. [\%]/ } \\
\text { Types of } \\
\text { Strategies }\end{array}$ & $\begin{array}{l}\text { Nev- } \\
\text { er [1] }\end{array}$ & $\begin{array}{l}\text { Some- } \\
\text { times [2] }\end{array}$ & $\begin{array}{l}\begin{array}{l}\text { Of- } \\
\text { ten } \\
{[3]}\end{array} \\
\end{array}$ & $\begin{array}{c}\text { Al- } \\
\text { ways } \\
{[4]}\end{array}$ & Mean & $\begin{array}{c}\text { Std. } \\
\text { Devia- } \\
\text { tion }\end{array}$ \\
\hline $\begin{array}{l}\text { Topic } \\
\text { Avoidance }\end{array}$ & 18.4 & 48.0 & 28.8 & 4.8 & $\begin{array}{c}2.200 \\
0\end{array}$ & .79312 \\
\hline $\begin{array}{l}\text { Message } \\
\text { Abandon- } \\
\text { ment }\end{array}$ & .8 & 34.4 & 45.6 & 19.2 & $\begin{array}{c}2.832 \\
0\end{array} \mid$ & .73736 \\
\hline
\end{tabular}


Meanwhile, Table 3 displays Approximation in mLearning communication context used as "Sometimes" [46.4\%] and "Often" [37.6\%] in their Compensatory Strategies [Intra-Actional]. This occurred as students need to compensate the lexical gap from their linguistic knowledge in communicating to let their conversation flow keep going; between the speaker and the addressee. Hence, the communication led to an alternative or related term that shares the target word structure, but less specific than the intended ones. For instance, students used the word 'consumers' to refer to 'hotel guests'. It showed that students' option is to use simple words or sentences that they were more familiar with in coping with their lexical gap. This is to avoid time consuming in understanding the communication in the conversation of mLearning context. As a result, students had to rely on their available linguistic system, which requires the least amount of time and effort to retrieve.

Next, it shows "Sometimes" [47.2\%] as the highest frequency of Word Coinage strategy used and "Often" [45.6\%] for Literal Translation. This reflected students had to rely on their first or native language [L1] to help them formulate hypotheses and rules of the English language [L2] in compensating for their lack of vocabulary or problems in constructing sentences. A sample of Literal Translation is 'Thing that make us to be health and beauty is what we talk together about'. Students were literally translating word per word from L1to L2 sentence structure; as in words, phrases or sentences as they think in L1 while interacting in L2 Meanwhile, it was found that students chose "Never" [34.4\%] use Foreignizing as their communication strategies in communicating in mLearning context. However, it was found that they were "Sometimes" [35.2\%] employed Foreignizing as for their communication strategies. Students opted for this strategy to refer to special terms such as names of diseases or traditional medications. As example, students tend to use 'kaki gajah' to refer to 'elephantiasis', or 'minyak gamat' for 'sea cucumber oil'. As these terms require a high level of knowledge and vocabulary in L2, students chose to Foreignizing as it is a faster and an easier way to get their message across to preserve the mutual understanding between the speaker and the addressee in a conversation.

Besides that, in a Compensatory Strategies [Intra-Actional], students "Often" [36.8\%] use Circumlocution as to describe or explain the characteristics of an object or action that they described instead of using English language item, for instance, they used the word 'black oval bowl on kitchen' as for 'pan' or 'wok'. This was done to self-repair in order to avoid communication breakdowns to occur; as well as to keep mutual understanding between the speaker and addressee of the conversation's content. Moreover, the highest frequency in the range of "Always" compared to any other communication strategies were Use of Fillers or Hesitation Device [33.6\%]. In other words, inappropriateness or incorrect words happened especially when students were facing difficulties in completing the sentence. Students had to manoeuvre their initial goal via an alternative plan in order to get the message across between the speaker and the addressee. This occurred as their intended message could not be fully expressed due to this used of communication strategy as they were experiencing limited linguistic resources.

Table 3: Compensatory Strategies [Intra-Actional]

\begin{tabular}{|c|c|c|c|c|c|c|}
\hline $\begin{array}{l}\text { Freq. [\%]/ } \\
\text { Types of } \\
\text { Strategies }\end{array}$ & $\begin{array}{c}\text { Nev- } \\
\text { er } \\
{[1]}\end{array}$ & $\begin{array}{l}\text { Some- } \\
\text { times [2] }\end{array}$ & $\begin{array}{l}\text { Of- } \\
\text { ten } \\
{[3]}\end{array}$ & $\begin{array}{c}\text { Al- } \\
\text { ways } \\
{[4]}\end{array}$ & Mean & $\begin{array}{c}\text { Std. } \\
\text { Devia- } \\
\text { tion }\end{array}$ \\
\hline $\begin{array}{l}\text { Approxima- } \\
\text { tion }\end{array}$ & 3.2 & 46.4 & 37.6 & 12.8 & $\begin{array}{c}2.600 \\
0\end{array}$ & .75134 \\
\hline $\begin{array}{l}\text { Word Coin- } \\
\text { age }\end{array}$ & 28.8 & 47.2 & 15.2 & 8.8 & $\begin{array}{c}2.040 \\
0\end{array}$ & .89262 \\
\hline $\begin{array}{l}\text { Literal Trans- } \\
\text { lation }\end{array}$ & 4.0 & 28.8 & 45.6 & 21.6 & $\begin{array}{c}2.848 \\
0\end{array}$ & .80738 \\
\hline Foreignizing & 34.4 & 35.2 & 23.2 & 7.2 & $\begin{array}{c}2.032 \\
0\end{array}$ & .93270 \\
\hline $\begin{array}{l}\text { Circumlocu- } \\
\text { tion }\end{array}$ & 10.4 & 38.4 & 36.8 & 14.4 & $\begin{array}{c}2.552 \\
0\end{array}$ & .86562 \\
\hline $\begin{array}{l}\text { Use of Fill- } \\
\text { ers/ Hesita- } \\
\text { tion Device }\end{array}$ & 3.2 & 29.6 & 33.6 & 33.6 & $\begin{array}{c}2.976 \\
0\end{array} \mid$ & .87496 \\
\hline
\end{tabular}

Meanwhile, out of the several sub-categories of communication strategies mentioned, students were found to employ a minimum of 3 communication strategies covering the 4 main categories of Compensatory Strategies [Inter-Actional]. Table 4 depicts students "Often" [54.4\%] or "Never" [2.4\%] use Asking for Repetition in their communication. Perhaps, it was rather embarrassing to explicitly and repeatedly ask for repetition from their group members. However, it is interesting to discover that students actually "Often" [40.8\%] turned to their friends who were more proficient in L2 as Appeal for Help, with its mean, 3.1360. It is pertinent to highlight that all participants, asked from their friends or classmates for lack of vocabulary in the mLearning context. The item of the questionnaire on it was, "I ask friends who are proficient in English". It illustrates that students were exploring most of the identified strategies to enhance the group interaction between them.

There was a clear indication of preference to certain types of communication strategies, as students "Sometimes" [40\%] use particularly Request for Clarification in solving their communication problems from their group members. To sum up, despite facing great difficulties in L2 interaction, students seemed to struggle to get their message across via several ways and means. In fact, their use of translators among their friends or classmates should be seen in a positive light as this strategic behaviour involves evaluation and analysis of the word options in determining its contextual appropriateness. Therefore, apart from having access to the translation of words, phrases or sentences; the translators or friends and classmates also would provide some options of words for students to choose from, thus helping their friends or classmates to expand their vocabulary in language acquisition respectively.

Table 4: Compensatory Strategies [Inter-Actional]

\begin{tabular}{|l|c|c|c|c|c|c|}
\hline $\begin{array}{l}\text { Freq. [\%]/ } \\
\text { Types of } \\
\text { Strategies }\end{array}$ & $\begin{array}{c}\text { Nev- } \\
\text { er [1] }\end{array}$ & $\begin{array}{c}\text { Some- } \\
\text { times [2] }\end{array}$ & $\begin{array}{c}\text { Of- } \\
\text { ten } \\
\text { [3] }\end{array}$ & $\begin{array}{c}\text { Al- } \\
\text { ways } \\
\text { [4] }\end{array}$ & Mean & $\begin{array}{c}\text { Std. } \\
\text { Devia- } \\
\text { tion }\end{array}$ \\
\hline $\begin{array}{l}\text { Asking for } \\
\text { Repetition } \\
\begin{array}{l}\text { Appeal for } \\
\text { Help }\end{array}\end{array}$ & 2.4 & 16.8 & 54.4 & 26.4 & $\begin{array}{c}3.048 \\
0\end{array}$ & .72797 \\
\hline $\begin{array}{l}\text { Request for } \\
\text { Clarifica- } \\
\text { tion }\end{array}$ & 8 & 21.6 & 40.8 & 36.8 & $\begin{array}{c}3.136 \\
0\end{array}$ & .77609 \\
\hline
\end{tabular}

\section{Conclusion}

The findings reflect the effort invested by students in making meaning in mLearning context; either as they express themselves or as they try to make sense of what their interlocutors are saying. Based on the findings, students' seemed to equalize face-to-face communication into mLearning environment by the communication strategies used. In order to inculcate positive communication strategies in mLearning context, such implications should be initiated as encourage students to be willing to take the risks in using communication strategies. For example, academicians could introduce L2 models on the use of certain communication strategies to students. Academicians could teach communication strategies to students by presenting linguistic devices, so that the students are aware of the appropriate approach of communication strategies to employ in a communication process. Furthermore, institutions should create pedagogies that may allow communication technologies assisting students' understanding of the literacy world. For instance, institutions may provide the design of a scope and a sequence that students can do with language. This could validate the levels of communicative competence that benefits employment readiness for the students. It is vital in reflecting students' personality in communicating with such apt communication strategies used for working environment soon. Hence, it is vital to educate and expose appropriate communication strategies in mLearning, as to date, the medium of communication is not merely limited to face-to-face but also in a form of electronic or virtual medium too. 


\section{References}

[1] Wagner ED. Enabling mobile learning. EDUCAUSE review. 2005;40[3]:41.

[2] Hussin S, Manap MR, Amir Z, Krish P. Mobile learning readiness among Malaysian students at higher learning institutes. Asian Social Science. 2012;8[12]:276.

[3] Nordin M, Embi MA, Yasin RM, Rahman S, Yunus MM, editors The mobile learning readiness of the post-graduate students. EABR \& ETLC Conference and proceedings; 2010.

[4] Traxler J. Learning in a mobile age. International Journal of Mobile and Blended Learning [IJMBL]. 2009;1[1]:1-12.

[5] Ndongko TM, Agu A. The impact of communication on the learning process: A study of secondary schools in Calabar municipality, cross river state of Nigeria. International Review of Education. 1985;31[1]:205-21.

[6] Ismail I, Gunasegaran T, Koh P, Idrus RM. Satisfaction of distance learners towards mobile learning in the Universiti Sains Malaysia. Malaysian Journal of Educational Technology. 2010;10[2]:47-54.

[7] Ellis R. The study of second language acquisition: Oxford University; 1994.

[8] Maleki A. Teachability of communication strategies: An Iranian experience. System. 2007;35[4]:583-94.

[9] Tarone E. Some thoughts on the notion of communication strategy. TESOL quarterly. 1981;15[3]:285-95.

[10] Tarone E. Conscious communication strategies in interlanguage: A progress report. on TESOL. 1977;77[194-203].

[11] Canale M, Swain M. Theoretical bases of communicative approaches to second language teaching and testing. Applied linguistics. 1980;1:1.

[12] Faerch C. Plans and strategies in foreign language communication. Strategies in interlanguage communication. 1983.

[13] Dörnyei Z. On the teachability of communication strategies. TESOL quarterly. 1995;29[1]:55-85.

[14] Dörnyei Z, Scott ML. Communication strategies in a second language: Definitions and taxonomies. Language learning. 1997;47[1]:173-210.

[15] Kalebić SČ. On the Use of Compensatory Strategies in Learner Interlanguage. UPRT 2007: Empirical Studies in English Applied Linguistics.269.

[16] Corder SP. Strategies of communication. Strategies in interlanguage communication. 1983:15-9.

[17] Brown HD, 吳一安. Principles of language learning and teaching. 2000.

[18] Woodrow L. Anxiety and speaking English as a second language. RELC journal. 2006;37[3]:308-28.

[19] Mustafa R, Zain S. Language anxiety in a remedial English language course: what teachers need to know. Journal of Linguistic Studies. 2009;2[1]:56-68.

[20] Hizwari S, Irma A, Hifzurrahman A, NorHaizar W. Second language anxiety among diploma students in Technical University [Universiti Malaysia Perlis]. 2008.

[21] Tarone E. Communication strategies, foreigner talk, and repair in interlanguage. Language learning. 1980;30[2]:417-28.

[22] Cohen AD, Dörnyei Z. Focus on the language learner: Motivation, styles, and strategies. An introduction to applied linguistics. 2002:170-90.

[23] Nakatani Y. The effects of awareness-raising training on oral communication strategy use. The Modern Language Journal. 2005;89[1]:76-91.

[24] Nakatani Y. Developing an oral communication strategy inventory. The Modern Language Journal. 2006;90[2]:151-68. 